\title{
A Case Study on Interactive Wordless Picturebooks and their Potentials within a Multilinguistic Classroom
}

\author{
Un estudi de cas sobre àlbums sense paraules interactius i el seu \\ potencial en una aula multilingüe
}

\author{
Un estudio de caso sobre álbumes ilustrados silentes interactives y su \\ potencial en una aula multilingüe
}

\author{
Maren Conrad. University of Erlangen-Nuremberg. maren.conrad@fau.de \\ https://orcid.org/0000-0002-0243-6081
}

Evelina Winter. University of Erlangen-Nuremberg. evelina.winter@fau.de https://orcid.org/0000-0003-0521-7615

\begin{abstract}
Magdalena Michalak. University of Erlangen-Nuremberg. magdalena.michalak@fau.de https://orcid.org/0000-0002-8571-8008
\end{abstract}

\begin{abstract}
The innovative wordless picturebook Was ist denn hier passiert? (What happened here?) illustrated by Neuhaus and Penzek (2015) offers a new form of multimodal storytelling by causally linking its pictures to an animated film via a QR code, thus switching from picturebook to animated film convention. This book is an example of combining literary considerations on multimodal wordless picture books with considerations on the possibilities and limits of multimodal storytelling, literature didactics and media didactics. The use of this innovative book is particularly interesting from the perspective of migration-related linguistically and culturally heterogeneous learning groups. We are interested in how the book can be used for literaryaesthetic and linguistic promotion within heterogeneous classes. This article presents selected results of an explorative study with primary school pupils with and without German as a second language. The pupils were videographed in groups during the reception process of the multimodal wordless picture book. The evaluation was carried out with a qualitative content analysis according to Mayring (2015). In addition to the different ways of accessing the picture book, the influence of the subsequent change of media, the change of genre, the follow-up communication as well as the multilingual access of the pupils on the reception is examined. It turns out that it is not the children's linguistic, but mostly their media experiences that influence their interaction with multimodal narrative wordless picture books. Our study showed that the change in the media plays a decisive role. Based on our initial results, we concluded that there is a great potential as well as challenges, in using the multimodal wordless picture books for heterogeneous classes in an inclusive learning environment, which are put up for discussion.
\end{abstract}

Keywords: Picturebooks, Multimodality, Second Language Acquisition, Inclusive Education 


\section{Resum}

L'innovador àlbum il·lustrat sense paraules Was ist denn hier passiert? (Què ha passat ací ?) il·lustrat per Neuhaus i Penzek (2015) troba una nova forma de narració multimodal en vincular causalment les seues imatges amb una pel-lícula d'animació a través d'un codi QR amb el que es passa així de la convenció de l'àlbum il·lustrat a la del cinema d'animació. Aquest exemple combina consideracions literàries sobre els àlbums il·lustrats multimodals en la didàctica de l'alemany, la literatura i els mitjans de comunicació. Açò es fa des de la perspectiva de grups d'aprenentatge lingüísticament i culturalment heterogenis relacionats amb la migració. L'article presenta els primers resultats d'un estudi exploratori amb alumnat de primària amb i sense l'alemany com a segona llengua. L'alumnat va ser filmat en grups durant el procés del llibre il-lustrat sense paraules. A continuació, es va realitzar una anàlisi de contingut qualitatiu tot seguint Mayring (2015). A més de les diferents formes d'accedir a l'àlbum il·lustrat, s'examina també la influència del canvi posterior dels mitjans de comunicació, el canvi de gènere, la comunicació de seguiment a més de l'accés multilingüe de l'alumnat en la recepció. Resulta que no són les experiències lingüístiques dels infants, sinó principalment les seues experiències amb els mitjans de comunicació, les que influeixen en la seua interacció amb els àlbums il·lustrats multimodals sense paraules. El nostre estudi mostra que el canvi en el mitjà juga un rol decisiu. Basat en els nostres resultats inicials, concloem que hi ha un gran potencial, així com diferents reptes, que també es discuteixen a les conclusions, en fer servir els àlbums sense paraules per classes heterogènies en un ambient d'educació inclusiva.

Paraules clau: Àlbum il·lustrat, multimodalitat, adquisició de segones llengües, educació inclusiva

\section{Resumen}

El innovador álbum ilustrado silente Was ist denn hier passiert? (¿Qué pasó aquí?) ilustrado por Neuhaus y Penzek (2015) encuentra una nueva forma de narración multimodal al vincular causalmente sus imágenes con una película de animación a través de un código QR, pasando así de la convención del álbum ilustrado a la del cine de animación. Este ejemplo combina consideraciones literarias sobre los álbumes ilustrados multimodales sin palabras con consideraciones sobre las posibilidades y los límites de la narración multimodal en la didáctica del alemán, la literatura y los medios de comunicación. Esto se hace desde la perspectiva de grupos de aprendizaje lingüística y culturalmente heterogéneos relacionados con la migración. El artículo presenta los primeros resultados de un estudio exploratorio con alumnado de primaria con y sin alemán como segunda lengua. El alumnado fue filmado en grupos durante el proceso de recepción del libro ilustrado multimodal sin palabras. A continuación, se realizó un análisis de contenido cualitativo siguiendo a Mayring (2015). Además de las diferentes formas de acceder al álbum ilustrado, se examina también la influencia del cambio posterior de los medios de comunicación, el cambio de género, la comunicación de seguimiento, así como el acceso multilingüe del alumnado en la recepción. Resulta que no son las experiencias lingüísticas de los niños y niñas, sino principalmente sus experiencias con los medios de comunicación, las que influyen en su interacción con los álbumes ilustrados multimodales sin palabras. En nuestro estudio se muestra que el cambio de medio juega un papel decisivo. Sobre la base de los resultados de este análisis inicial, se discuten la potencialidad y los retos de utilizar álbumes ilustrados multimodales sin palabras en las clases de alemán en un entorno de aprendizaje inclusivo.

Palabras clave: Álbum ilustrado, multimodalidad, adquisición de segundas lenguas, educación inclusiva. 


\section{Introduction}

The linguistic and cultural heterogeneity of learners in today's classes influences today's teaching, which is why there is an urgent need of an innovative approach. Contemporary lessons try to reach students with different linguistic knowledge and experience in dealing with (digital) texts. In terms of teaching ${ }^{1}$ German literature and language, this could mean looking for media that are accessible to readers of a certain (young) age and (low) experience. Therefore, the questions arise as to which literary pieces could be accessible to all pupils and what didactic material could be designed for these pieces to be prepared for the classroom. This should be considered particularly in relation to the digital experiences of the pupils. One possibility is to use structurally all-inclusive artifacts in class to level out possible differences between media and language competences. We decided to do so with an innovative wordless picture book, published in 2015, that worked on the basis of digital expansion, multimodal and transmedia storytelling, and was Therefore, the questions arise as to which literary pieces could be accessible to all pupils and what didactic material could be designed for these pieces to be prepared for the classroom. This should be considered particularly in relation to the digital experiences of the pupils based on picture-narrative. This sort of 'silent book' explores new forms of media interdependence by breaking off with the epistemic hierarchies of rank and meaning which used to be typical for classic picture books (Kümmerling-Meibauer, 2015; Kriechel, 2020). Thus, they break with conventional reading habits - as the text functions no longer as the dominant carrier of meaning. Our wordless picturebook Was ist denn hier passiert? (What happened here?) (Neuhaus \& Penzek, 2015) works with media changes by offering reference to an animated film via the QR code, which offers an inclusive option of reading and helps to make the story accessible. Only those who activate the QR code can find out how the curious scene depicted in the picturebook came about - the clip reveals the answer to the title question "what happened here?". Through this media progression, experimental picture books of this kind playfully expand the digital knowledge of their recipients. At the same time, they offer different ways of developing aesthetic experiences and could offer new learning activities through their intricacy.

Additionally, multimodal picture narratives work especially well in the form of wordless picture books: books which tell a story through illustrations without any written text (Bosch, 2014; Reese, 2015). Individual interpretations of the pictures will take place regardless linguistic barriers to understanding or linguistically formulated trains of thought (Dammann-Thedens \& Michalak, 2011). Wordless picture books can be beneficial primarily in so called learning groups. Such groups are linguistically

\footnotetext{
${ }^{1}$ In Germany, both literature and language teaching are one subject: German Studies.
} 
heterogeneous due to their families' backgrounds. Innovative multimodal storytelling is thus oriented towards heterogeneous dimensions of culture and society in the sense of ethnic, cultural, and linguistic diversity and their representation (Bittner, 2011). It is particularly suitable for a teaching which is focused on media literacy and literary aesthetics as well as linguistic competences in learning settings focused on diverse groups. Also, the book itself is well suited for lessons in any language and culture, which is why we present our findings and thoughts on teaching opportunities in this article to an international readership.

Our study and the findings presented in this paper discuss the opportunities and challenges in dealing with multimodal wordless picture books which are used for German lessons to a group of learners with divergent linguistic and cultural backgrounds as well as different levels of media competence. Using the book Was ist denn hier passiert? (What happened here?) as an example, we have investigated how

Our main interest lies in the examination of how the reception of a literary piece is influenced by multimodality and the change of media, i.e. digital expansion. Moreover, we will focus on the cross connections between the subjects[...] in the sense of promoting media education children with and without knowledge of German handle such picture books and which factors influence their reception. The article contains only a selected amount of detailed information on our study, which has been completed (Conrad \& Michalak, 2020) and aims to reflect upon its abstraction for inclusive teaching, and its dimensions of differentiation (Boelmann \& König, 2019; Brand, 2016). Therefore, in the following sections, we will discuss the results of our study with regard to the first and second language approaches, and the teaching-learning offerings designed for participation. Our main interest lies in the examination of how the reception of a literary piece is influenced by multimodality and the change of media, i.e. digital expansion. Moreover, we will focus on the cross connections between the subjects, be it German (as a foreign language) or Music and Art, in the sense of promoting media education (Jörissen et al., 2019). Therefore, we aim to derive principles of teaching for German (as a foreign language) under the conditions of digitisation.

\section{Research Context}

Picture books as part of the field of children's literature have undergone a change in aesthetics, content and book design and such developments "certainly change the modes of story-telling in picturebooks and other children's media in the long run, introducing children to transmedial narration" (Kümmerling-Meibauer, 2015, p.261). Many developments have offered changes towards innovative forms over the past 20 years, influenced by constantly improving capabilities of print media (Kurwinkel, 2017). Children's literature is therefore becoming increasingly complex in terms of topic and content 
as well as design and artistic qualities (Kümmerling-Meibauer, 2018; Krichel, 2020). At the same time, our digital culture of the 20th and 21st century is more and more focusing on visuality as the centre of medial representation (Schmitz, 2011). This effect also explains a certain trend towards multimodal communication, i.e. communication via parallel channels and with several senses (ibid.) that is becoming omnipresent. These developments have made profound impacts on the new ways picture books 'work' nowadays.

\subsection{Multimodal children's literature as digital artifact}

Looking at the field of children's literature in its historical development, it appears that multimodality has been constitutive for children's literature from the very beginning. Since the 19th century, children's literature in particular has naturally used modal codes other than verbal language and writing (Weinkauff \& Glasenapp, 2010). This tendency towards multiple coding and the associated semiotic complexity in pictorial, lyrical-musical elements of early picture sheets or panorama books of the 19th century is already evident. The multimodality of children's literature has always been embedded in a specific historical context of media use and is mostly implicit at its beginnings, meaning that the integration of a medium takes place 'inwardly' through representation (e.g. the picturebook as a museum room in the 19th century or the picture of a television set in a picturebook in the 20th

The multimodality of children's literature has always been embedded in a specific historical context of media use and is mostly implicit at its beginnings, meaning that the integration of a medium takes place 'inwardly' through representation century). More recent multimodal narratives, on the other hand, are often explicitly designed. They use multimodality to strive for an interactivity with the recipient, which is mostly explicitly addressed. The inclusive picturebook Maulwurf Max (Mole Max) (Rhyner, 2018), for example, stimulates interaction with the book by constantly changing the mode in which the story is perceived, allowing children not only to read, see and hear, but also to smell and touch the narration and thereby experience the things that the blind mole hero perceives on his journey. With shifting the element of importance from one century to another, from book audio-visual artefacts to increasingly digital and interactive media (Niklas, 2012; Schrenker \& Beyer, 2014), the picturebook today is more and more an essential part of a transformed culture that is shaped above all by audio-visual media. It is also integrated into cultural developments and changes and shaped by more open narrative concepts (Thiele, 2003; Abraham \& Sowa, 2016; Scherer \& Volz, 2016).

Therefore, "[w]hen analyzing [...] picturebooks with their diverse visual and linguistic codes, their multimodal character demands the specific capacity of code switching." (Kümmerling-Meibauer, 2015, p.258). Additionally, it is possible to speak of an emancipation and associated mediatisation of the picture book, as modern digital tools and design options are increasingly expanding the traditional 
picturebook (Tabbert, 2010). Explicit multimodal narratives can therefore be defined as picture books that exhibit both their own mediality and the mediality of other artefacts by metareferentially transcending conventionalised narrative boundaries (Klimek, 2010; Kruse, 2014).

In the course of a "pictorial" towards a "multimodal turn" (Bucher, 2012), the multimodal character of the picturebook has been strengthened. Multimodal narratives in children's literature mainly work by combining different visual codes, e.g. texts, comic, illustration and photography. But as the medial discourse evolves, so does multimodality within children's literature. In recent innovative publications within the field, digital elements have played an essential role in broadening the potential of transmedia storytelling within children's literature. They could turn a single book into a multimodal artefact offering a world of possibilities, that can not only be seen, but also heard, felt or even smelled or interacted with (Serafini, 2010). This kind of multimodality goes beyond the concept literary studies refer to as 'intermediality'. Intermediality is a concept to distinguish references between at least two forms of media or sign systems which are perceived as distinct, but are combined within one artefact (Rajewsky, 2018). Multimodal artefacts depict, integrate, or cite another sign system within their own medium/sign system. Multimodal picture books go beyond depicting and tell stories according to this concept mostly by using several different visual and interactive/ digital levels. Consequently, they also pose the question of 'how the story is told' in a new way and distribute the actual story on multilayered medial and modal levels, for which they use a vast variety of semiotic resources. Nowadays the semiotic complexity of these artefacts is constantly increasing, as these innovative artefacts work by adding interactive dimensions to the narrative (Siefkes, 2015; Bucher, 2010). In innovative children's literature the act of 'reading' therefore involves decoding an artefact far beyond a text-centered reception, it includes being a visual, acoustical, interactive, haptical or olfactory challenge.

\subsection{Extension to wordless multimodal picture books}

Innovations in children's literature use digital media for their multimodal narrative and may potentially create new opportunities to engage young readers and may help to develop skills which students need to successfully participate in a digital society today (Hovious et al., 2020; Renck et al., 2002). The multimodal narratives that we focused on for our study were part of the picturebook Was ist denn hier passiert? (What happened here?). It features twelve unusual and artistically sophisticated pictures without text. ${ }^{2}$ Each of these absurd, multi-layered images raises the very same question that is asked in the title of the book, and encourages the reader to guess: what happened here? This book motivates the reader to search for clues and creatively explore the background story. All images are accompanied

\footnotetext{
${ }^{2}$ Exemplary pictures from the book with the corresponding extension by an animated film can be found on the homepage of the Tulipan publishing house.
} 
by QR codes that lead to the short, 'silent' (wordless / no accompanying language) story-animated films with music that reveal the secret of each image, thus carrying out media change from book to screen. In this way, the QR code not only provides a resolution for the background story but also functions as a reward for the reception of the images in the book. In its challenging hybridity, multimodal narration could be found at the interception between image, moving image, narration, music, and switching from one medium to another (book to screen). A prerequisite for developing the complex relationship between image and animated film is the existence of multimodal and cultural competences, because it is only through the change of mode that the visual conventions of two very different kind of media can be clearly recognized and decoded (Kümmerling-Meibauer, 2012; Serafini, 2010). At the same time, however, the challenging conditions of reception require of the picturebook reader certain openness towards the construction of the story's meaning and sense (Neuhaus, 2014). In other forms of children's literature multimodality might be part of the artefact via an enclosed piece of music (CD), an attached arts\&crafts offer, an app or a QR code which would lead directly to an extension of what is depicted in the book and thus would transfer the interaction with the book to digital level. The boundaries of the respective narrative world are therefore crossed through interactivity. By means of its extensions, components of explicit virtuality and materiality are paired with the medium of the book (Hopp \& Lieber, 2013). In children's literature and especially in picture books, this crossing of boundaries is always instrumentalised as a moment of surprise, curiosity, playful encounter and excitement for the recipient. This brings together various participants: (picture) bookmakers and authors, illustrators and potential readers: they all share an interest in a book as both a cultural asset and an artefact of a specific definition of education, but also as an object of reading, a place to acquire literacy and narrative competence that initiates linguistic and aesthetic action and reflection. This makes the picturebook an innovative genre with media-integrative and mediaconvergent characteristics which also are more and more subject to the conditions of digitisation (Ritter, 2014).

\subsection{Multilingual pupils' interaction with wordless picture books}

Wordless picture books and especially its multimodal extension, as it is described in the chapter above, is an important tool for storytelling in multicultural classrooms. Accordingly, a look at the target group is crucial. The children are not only multilingual but also multicultural and thus bring with them diverse linguistic, cultural, educational, and also literary previous experiences (Ahrenholz et al., 2013). So, they have different levels of proficiency in the target language German depending on the length of stay in the destination country. Thus, the different linguistic levels in the target language have a direct influence towards the access to the wordless picture books in German. For language beginners, it has therefore been shown that the division of the reading process into three phases (pre-, while- and post- 
reading) according to Rosebrock \& Nix (2015) must be expanded for this target group to include the phase of orientation or encounter with this genre of wordless picture books (Dammann-Thedens \& Michalak, 2012). This helps pupils find fitting vocabularies and categories to the objects and activities in the target language German and to overcome the hurdle of the parallelism of picture development and linguistic transformation (Dammann-Thedens \& Michalak, 2012). The pupils' first languages are also different and so are their proficiency levels, which depend crucially on socialization (Eßer \& Nimet, 2018). Some of the multilingual pupils can read and write in their first language, while others may completely refuse to use their first language.

Therefore, wordless picture books are a good starting point. It is to be expected that especially multilingual children will benefit from dealing with wordless picture books, as they have an overall language repertoire that allows them to switch between languages and this is particularly useful in negotiation processes, as it reflects the pupils' competent use of languages (Tracy, 2008). This engagement with visual stimuli seems to require a multilingual exchange between pupils at different stages of reception. For multilingual children, picture-based storytelling with its multimodal approaches opens a variety of possibilities for reception that go beyond linguistic approaches. Each child, regardless of language, is encouraged by the pictures in the wordless picturebook to construct its

Wordless picture books and especially its multimodal extension, as it is described in the chapter above, is an important tool for storytelling in multicultural classrooms. [...] The children are not only multilingual but also multicultural and thus bring with them diverse linguistic, cultural, educational, and also literary previous experiences own meaning of the story and thus uncover the narrative structure (Wieler, 2015). This construction of the meaning or narrative structure is based on the individual cultural prior knowledge as well as acquired visual literacy which is used by de- and encoding symbols and signs in pictures (Kümmerling-Meibauer, 2006). The wordless picturebook here requires not only the identification of the various pictorial signs, but rather also the uncovering of the underlying layers of meaning. Thus, the so-called "closed-class-lexical-items" presuppose culturespecific knowledge, which must be decoded with the help of the "referential code" (Krichel, 2020). The previous findings of research on wordless picture books do not consider the handling of multimodality or the inclusion of childrens' multilingualism and how they use it in reception (Krichel, 2020; Wieler, 2015). Previous studies have mainly focused on multilingual pupils' engagements with short picture stories and not with narrative wordless (multimodally extended) picture books and the extent to which access or interaction varies based on the individual first languages is not investigated (Kalkavan-Aydın, 2016). In the study, we will examine this connection between narrative multimodal wordless picture 
books and multilingual negotiation processes plus the potentials of wordless multimodal picture books for working with multilingual pupils.

\section{Methodology}

Realisation of multimodal storytelling takes place through images and moving pictures, this allows for more levels of interpretation than a written text and provides different ways of exploration and linguistic development (Dammann-Thedens \& Michalak, 2012; Renck et al., 2002). Due to these characteristics, multimodal wordless picture books such as Was ist denn hier passiert? (What happened here?) offer beneficial possibilities for use in all-inclusive learning settings, especially in culturally and linguistically heterogeneous learning groups. To work on this assumption, our exploratory qualitative study 2018 (Conrad \& Michalak, 2020) examines the literary-aesthetic and linguistic approach of primary school pupils with and without German as a second language to the multimodal narrative complex of Was ist denn hier passiert? (What happened here?). Therefore, we focus on the following questions:

- Do students' approaches vary depending on their media, language and school experiences?

- To what extent does the change of media play a role in their reception?

\subsection{Sample}

The sample consists of 23 primary school pupils (in Germany) with an average age of 10.08 years (SD = 1.98). Twelve children defined German as their second language. Seven stated that they spoke Arabic, two Romanian and three Russian as their first language. The range of German language learning time was between zero and three years. The children's language competence showed a clear spread between the learners with German as their second language and German as their first language. All pupils achieved an average of $39.34(S D=18.33)$, those with German as their second language $(L 2)$ an average of $36.27(S D=14.47)$ out of 100 possible points in the C-Test.

It is important to bear in mind that the students are learners who live in Germany and therefore their first language (L1) utterances do not correspond to the language variety spoken by children of that age in the corresponding country of origin.

\subsection{Implementation}

In order to answer the listed research questions, the children's general linguistic competences in German were assessed in advance with a C-Test (Eckes \& Grotjahn, 2006). According to the classical principle of erasure, the second half of every second word is erased. A maximum of 100 points can be achieved, whereby only completely correct words are counted. This test was implemented with the 
aim of comparing the results to see if there are differences between linguistically stronger and weaker pupils.

By means of a semi-standardised questionnaire, it was also possible to collect language biographical data from the pupils to draw conclusions about their school experiences, reading experiences and the time they spent learning German. Furthermore children $(n=23)$ with different previous linguistic and aesthetic experiences were assembled as one group and filmed in a cooperative process of understanding four pictures and writing down their stories based on what they understood.

The implementation took place in one informal meeting, which was about 45-60 minutes in total (ca. 15 minutes for each round/ picture). In was structured in three steps:

1. In the first-round, students were divided into groups of three according to their first languages (L1). The groups were asked to deduce the meaning of the first picture and its background story and to write down the results in their first language (L1).

2. In the second-round, the composition of the groups remained unchanged, however the children were given the task of talking in German as their second language (L2) to construct the narrative.

3. In the third round, the pupils were reassigned, so that heterogeneous groups were formed with regard to the first languages. This allowed German (L2) to be used as the only possible language of communication in the respective recipient group.

The focus group discussions were then transcribed in a teamwork cooperation by students and researchers, working in teams on the interpretation and transcription of the video material, those whose mother tongue is Arabic, German or Russian focusing on the equivalent recording. Since the exchange and writing of the learners took place in the first and second language settings the data reflecting different approaches to the picturebook in the first and second language provides valuable information and can also be analysed.

The aim of qualitative content analysis (Mayring, 2015) is to filter out certain aspects from the material, to lay out a cross-section of the material under previously defined classification criteria or to assess the material based on certain criteria. In this explorative study, categories for dealing with wordless picture books were formed in the deductive analysis process, which were first defined and then inductively differentiated into further subcategories. In addition, the children wrote a written text for each received narration in a cooperative setting. 


\section{Findings and Discussion}

The result of the analysis led to the following categories, which we will discuss in the following:

- Influencing reader reception through paratexts

- Change of media

- Digital entanglements and intertextuality

- Follow-up communication

- Multilingual learning

These categories show the potential of multimodal storytelling. In terms of content, we were able to identify an interface in learners' reception, that was decisive whether the story was created before or after the first change of media. In the following analyses, the individual categories are described with the help of evidence from the group discussions.

\subsection{Influencing reader reception through paratexts}

During the first round, the recipients are confronted with the challenge of recognising and putting to use the connection and complex relationship between image and animation. The analysis of the video recordings of the group discussions show that the actual sign system and the complexity or materiality of the image play almost no role in receptions processes. It is not the picture and its details, but the event within the picture that prompts the absorption of the narrative, whose content and stylistic conventions are the subject of an intensive exchange among the children. This shows that the advantage of the book is its strong focus on eventfulness. This is already emphasised by the title of the book and expanded by the digital extension of the book.

The change of mode represents a hurdle for the recipients in that the conventions of both media have to be deciphered: certain visual and cultural symbols and codes that go beyond static visual stimuli (Danner, 2009; Renck et al., 2002) must be recognised (Kümmerling-Meibauer, 2012). The recordings thus confirm that dealing with such books requires guidance in order to get to know the principle of the story. But they also show that their use is well suited for inclusive learning settings. Because even if the children bring along quite different media literacy, the change of media functions as a creative outlet and connecting element for a productive reception (Serafini, 2015). The second round - once the concept has been recognised - shows greater equality between the children in terms of content comprehension in the attempt to invent a story in a collaborative process, as it is now not a matter of prior knowledge and narrative conventions, but of creativity and imagination. Here, language barriers or reading socialisations do not create hierarchies in the design of the narrative. At the same time, it can be shown that after the first round of the second picture, the pupils look at the picture as a medium with content-carrying details in a much more concentrated way and set off on a 'search for clues' (see 
fig. 1, line 3). In the picture the pupils see an organ grinder and musical notes flying around and a girl with a dog leash hanging from her hand leading to an inflated flying dog. You would think the pupils would focus on this. However, they focus on the newspaper (fig. 1, line 5) which is lying on the righthand side in the corner; this can be now taken as a symbol that they do not want to miss out. By getting to know the book's concept, a learner is prepared to pay attention to details in the picture as if using a magnifying glass, which could have a meaning for the background story. Again, this step is independent of the children's language skills, age, and previous digital experiences.

1

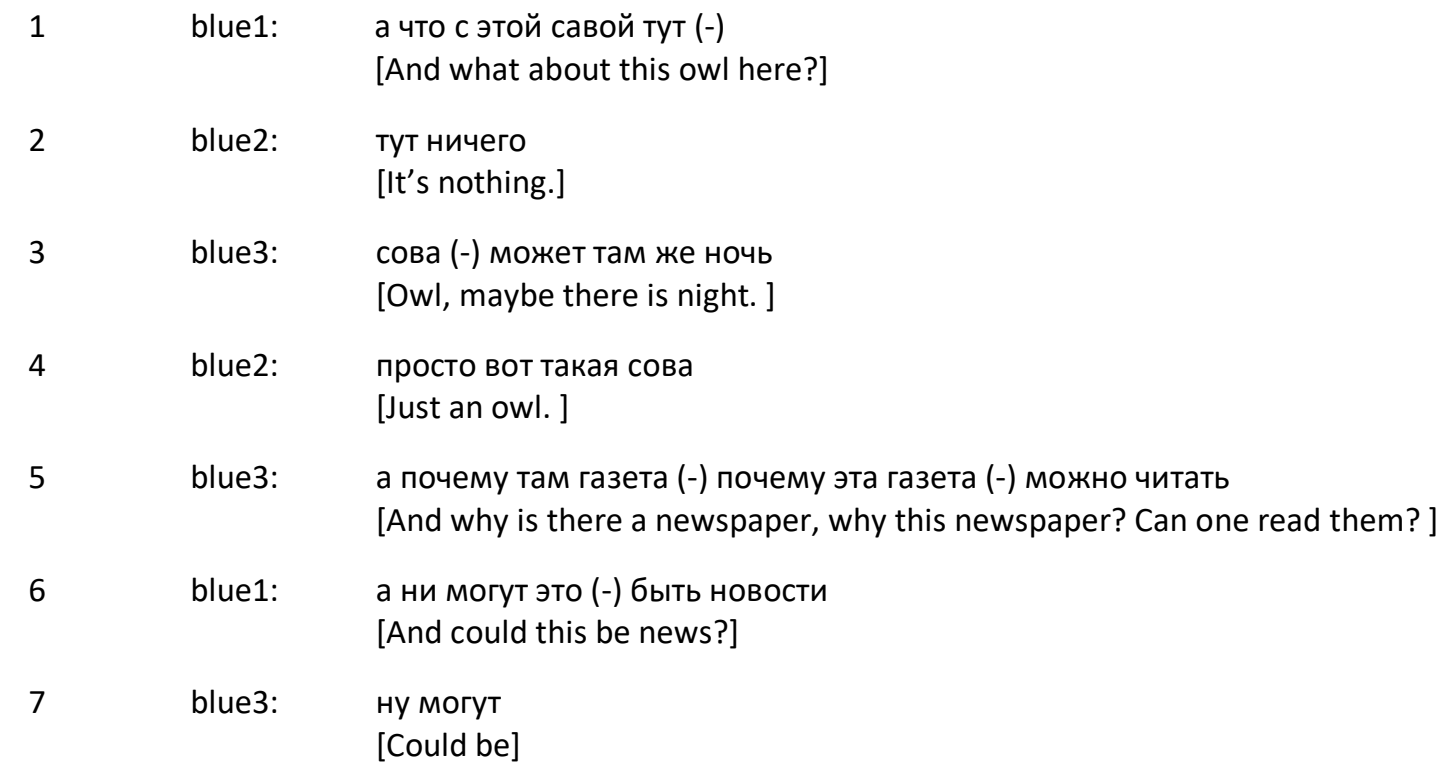

Figure 13: Group A1 (blue) (L1 Russian, Age: 7/8/8, c-test: 14/44/23; German learning time: 18 months/24 months/born in Germany; picture: Girl with flying dog)

As a conclusion from these observations from a language and literature teaching point of view, multimodal narration requires an orientation towards familiar literary text forms. This guidance may be offered by the paratextual elements of a book, but also by a well-prepared setup for a lesson. This allows linguistic structures specific to text forms to be used effectively as a support for the development of narratives. The connection between the image, the QR Code and the cartoon behind it as well as the title of the book and the associated guiding questions must be conveyed. In this way, the link between the final state, which is presented by the picture, and the initial state, which the students have to guess, is successfully established. Therefore, it is useful to consciously integrate the paratexts, in our case meaning the title and a comic, introducing the idea of the book, into the tasks first and then to discuss the first picture together so that the students can understand and apply the

\footnotetext{
${ }^{3}$ The transcriptions of this article are translated by the authors with the aim to make the dialogue of the children understandable for the reader.
} 
concept of the book. This may be particularly helpful for younger children who tend not to reconstruct the story as requested, but simply to continue telling it.

\subsection{Change of media as access to fictionality}

Multimodal storytelling builds on children's digital experiences and enables them to improve their media competences and expand those by multimodal means. In the group discussions, for instance, it

In the conversations, it becomes clear that most children choose a conventional approach to books known to them from the educational or reading context, that anticipates literary narration. Reading and writing socialization therefore essentially determined their initial reception. becomes clear that most pupils are already familiar with the use of a QR code. The ability to work with the QR Codes strongly increases the children's intrinsic motivation. If they are not familiar with the concept of the QR code, they can improve their media competence on a technical level. In addition, the multimodal picturebook offers room for the perception of multimodal diversity in literary works. The multimodal approach of the book is particularly evident in the first stage BEFORE the change of media, when the children try to find a first 'answer' to the question 'What happened here?'. The constant and intensive negotiation of the 'genre' of the image takes up a large part of the communication. In the conversations, it becomes clear that most children choose a conventional approach to books known to them from the educational or reading context, that anticipates literary narration. Reading and writing socialization therefore essentially determined their initial reception.

The negotiation of factual versus fantastic-fictional text ("Is this a fairy tale?" vs. "No, this happened for real") takes up a large part of the first conversation. In this way, group discussions are used to deliberate what is possible or permissible: 
1 yellow2: das auto kann fliegen

[the car can fly]

yellow3: (lacht)

[(laughs)]

2 yellow1: lach nicht (--) ist es ein märchen

[don't laugh (--) is this a fairy tale?]

3 yellow3: das ist kein märchen (-) das ist in echt passiert

[this isn't a fairy tale (-) this happened for real]

4 yellow 1: in echt?

[for real?]

5 yellow 3: ja (-) es gibt keine fliegende auto

[yes (-) there are no flying car]

Figure 2. Group B1 (yellow) (L1 Arabic, Age: 10/11/14, c-test: -/41/21; German learning time: 18 months/36 months/born in Germany; picture: Old lady hovering in a car)

The change of media to the animated film is the initial spark for creative rethinking and the subsequent approaches, which are now multimodal and attempt to interpret the images beyond literary narrative conventions.

AFTER the change of media, the children's media experiences determine approach and reception. The groups realise that despite the initial picturebook format the story is told according to cartoon conventions, which uses a fantastic-fictional story language. Media experiences now determine approach and reception:

1 blue3: пиши что он крутит музыку (-) а девочка (-) слушает (-) она купила себе шарик всё [Write that he is spinning the music and that the girl is listening and bought a balloon. End]

2 blue2: $\quad$ нет это (-) может собачка быть и (-) надуться

[No this can be a dog and he inflated himself]

3 blue1: $\quad$ ето просто (-) как-то это (-) что то придуманная (-) вы видели спаун (-) все думали что она там что-то (-) нормальное делал но она из чего-то нормального (---) с ней играли емоции ето - фантазия тут

[It's just something that's kind of made up. Have you seen the movie "Spawn" (movie about a secret agent with super powers, on a comic strip)? Everybody thought that she was somehow doing something normal, but she made out of something normal...(drops the sentence as language skills in L1 are not sufficient). She acts out of emotion. This is fantasy. ]

4 blue3: может её надули (-)

[Maybe he (the dog) has been inflated]

Figure 3. Group A1 (blue) (L1 Russian, Age: 7/8/8, c-test: 14/44/23; German learning time: 18 months/24 months/born in Germany; picture: Old lady hovering in the car) 
The challenge of understanding the narrative that is non-conventional due to its multimodality and non-linear character because of the coupling of narrative structure and media change often generates a 'collective overload' during the first reading passage (fig. 3, line 3). This, however, is cancelled out, e.g., by the change of media to cartoons, and creates a positive effect of understanding and cognition, hence lays the foundations for multimodal competence.

The perception of the change of media facilitates understanding in general and the understanding of fictionality in particular. The cartoon offers a different concept of fictionality, so that after the first example, the recipient understands more quickly the idea, overcomes the excessive demands, and rediscovers the 'illogical' that goes along with the change of media, as a fantastic and creative potential for dealing with the object. Surely this is also central potential quality of multimodal picture books, which stimulates reflection on one's own reading, learning and media socialisation. Hence, they also make the negotiation of one's own narrative in group communication a subject of discussion.

At the same time, this type of media change influences the teaching approach, as there is a risk of comparing the children's story with the authors' shown in the cartoon. If one analyses the children's facial expressions when they first watch the film belonging to the first picture, disappointment can be observed regarding the dissolution of the story. Such pupils' exclamations as "How illogical. What? Totally illogical" occurred after the change of media very often. Students show their surprise, and this can be interpreted as an understanding of the story as fictional, but also as displeasure with the plot portrayed. Once the children's perceptions are shaped by their previous educational experiences in such a way that they see the cartoon as the only real solution, their motivation in making up their own stories based on the next pictures may be impaired. This could be counteracted didactically by rewarding creativity and inventiveness of the stories created as alternative narratives. In cooperation with the author, who offers respective workshops, it would even be possible to realize an alternative story as a stop-motion film. In this way, in connections with the subjects of art and music, one can offer a wide range of design possibilities. By adding music, low-threshold access to musical-aesthetic experiences or processes of "being creative" with music can be made possible (Ahlers, 2017). This access can be easily done by using tablets (like the App Yousician) or smartphones (e.g. Garage Band) in classes. Here, pupils can compose and incorporate their own music to the stories. In addition, the artistic techniques of the book can be taken up and developed further. For example, collage-technics do not necessarily have to be retained as the main form of the visual expression; here, too, other digital forms of art teaching with smartphones can be used, for example with the help of the PixArt app, which enables different designs, such as transferring photos into cartoons. 


\subsection{Digital entanglements and intertextuality as a form of approach}

Through the complex cultural references and quotations in the context of multimodality, the book Was ist denn hier passiert? also offers intertextual or intermedial points of approach. These are supported by the openness of the narrative's range of meaning and are promoted by digital links. In this way, it is natural for the pupils to switch between the different media and to establish references between pictures, books, music, and film. They have to rely on their knowledge of familiar pretexts and their media experiences for successful exploration of the images.

A change of media is already anticipated in the search for a suitable narrative in the story about the old lady in the flying car entitled "Agent Grandma 007" (Group red, L1 Arabic). The group thereby places the picture in the context of its own filmic association and draws on the James Bond film/book series as an intertextual narrative and explanatory pattern for the obviously action-packed picture composition and the inventory of the picture (car/city). The children also refer to films such as Superman or Spawn (Group yellow, L1 Russian, fig. 3) in order to explain the

Multimodal narratives, which are expanded digitally and through print media, are therefore inclusive to the extent that they promote new forms of multimodal competence in all recipients. In addition, it is particularly interesting with regard to action and production-oriented literature teaching, as several implementation possibilities can be creatively introduced here. image of the grandmother flying in a car with the phenomenon of superpower. Another group (purple, L1 German) finds a current German pop-cultural and musical context. Based on the expression 'take off', they use the lyrics of "Astronaut" by Sido featuring Andreas Bourani, omnipresent on German radio in 2018, as an association for the flight scene depicted. The images are also associated with wellknown children's songs. This illustrates that intertextual and intermedial links extend the creative approaches so that the children's knowledge from film and music is used to interpret the images and invent their own stories. It is these elements in particular that can be seen as an opportunity for the didactic use of this genre, for example by stimulating the associations in the task at hand. The potential of multimodality becomes especially clear this way, as the levels of diversity, observation and insight are always addressed here through their own materiality. Multimodal narratives, which are expanded digitally and through print media, are therefore inclusive to the extent that they promote new forms of multimodal competence in all recipients. In addition, it is particularly interesting with regard to action and production-oriented literature teaching, as several implementation possibilities can be creatively introduced here. For example, QR-codes can be very easily created by the students and thus enrich and continue their reception. In this way, students can create online stories by permanently anchoring individual links to pictures, videos, graphics, texts etc. (Krommer, 2016). This represents a great potential for interdisciplinary project work. 


\subsection{Follow-up communication as an open learning setting}

The complexity of the multimodal picturebook is a central opportunity due to its facilitated accessibility, for example in the form of its 'silent' nature. In this way, the moment of creativity is at the centre of a collaborative, active and explicitly non-rule-bound exploration (Conrad \& Michalak, 2020). To do justice to the different communication skills in literature teaching, communicative, language-bound requirements must also be modified. In addition to the conceptual expansion of storytelling and communication in inclusive settings, the focus is on active participation in literary learning processes (Thiele \& Bosse, 2019). This tendency of multimodal innovation, which literally provokes a creative approach to new formats, opens up central multimedia and communicative options within the framework of media-integrative and identity-oriented German teaching (Frederking, 2013). The collaborative follow-up communication (Rosebrock \& Nix, 2015) facilitates the development of image narration both literarily and linguistically. Besides, the 'draught horse effect' (Helmke 2012), whereby weaker or insecure children are pulled along by the stronger ones to initiate "the zone of the proximal development" (Vygotski, 1987), also applies to inclusive, collaborative learning.

Looking at the data material of our study, it can be observed that the cooperative examination of the book leads to various discussions on several levels. Not only the genre (fig. 2, I. 4) is discussed, but also the linguistic application, the difference between oral and written narration, one's own linguistic and narrative skills (fig. 5, I. 5, 9) as well as the content of the story and its narrative characteristics. Decisions on the division of work and the allocation of responsibilities also become the subject of the discussions.

Far more important, however, is that the potential of follow-up communication lies in the fact that the subjective development and communicative appropriation or processing of the reception often interlock and influence each other (Dammann-Thedens \& Michalak, 2011). Through the exchange about the individual receptions and interpretations based on the images, a common construction of meaning is made possible; it goes beyond the individual narrative as well as linguistic competences. The students take up the ideas of the others, reflect on them, and in this way construct a coherent story together:

1 green3: ein auto ist runtergefallen [a car fell down]

2 green2: es stimmt (-) das ist eine Wolke (-) die ist von einer Wolke gefallen, ja (--) passt schon [it's right (-) that's a cloud (-)she fell down from a cloud (-) yes (-) it fits ] 
green3: ja ist eine wolke

[yes that's a cloud]

green1: $\quad$ nein (-) aber es könnte auch sein dass zum beispiel da unten eine baustelle war (-) also eine rampe

[no (-) but it can also be that there was a construction underneath (-) means a ramp]

green3: Ja (-) so wie in jedem (-) wie in jedem guten cartoon

[yes (-) how in every (-) in every good cartoon]

green2: $\quad$ von hier und strom (deutet auf das Bild) und muss von da kommen meine ich (--) oder (-) ja (-) einfach eine Oma mit einem Auto was durch die Luft fährt

[from here and power (points to the picture) and must come from there I mean (-) or (-) yes (-) just a grandma with a car driving through the air]

7

green3: $\quad$ nein nein (-) Superman hat sich unsichtbar gemacht und trägt das Auto

[no no (-) Superman has made himself invisible and carries the car ]

8

green2: $\quad$ Superman hat sich in diese oma verwandelt

[Superman has turned into grandma]

green3: finde ich das mit über eine rampe fahren und hochspringen besser (-)

[I liked the idea more to drive over a ramp and jump up]

Figure 4. Group A3 (green) (L1 German, Age: 11/12/11, c-test: 58/58/60; German learning time: born in Germany; picture: Old lady hovering in a car)

As a consequence, particularly collaborative learning should be promoted through appropriate tasks and negotiation processes must be initiated.

The title of the book and its concept offer a suggestion or a starting point for follow-up communication. From the beginning, the focus is therefore placed on the action or an event structure in which both a chronological sequence and causal relationships play a decisive role. Although the interpretation of the depicted individual images or the individual elements is important from an intercultural point of view, it is negotiated in the consensus of each group in the context of the common story as a whole and thus does not change the plot. For example, geese are identified as chickens, or a dog is identified as a goat. For the development of the narrative, though, this is irrelevant. Cultural conditions or linguistic insecurities are not essential to the negotiation. The unconventionality of the material and the narrative as well as the medial rule violations of the multimodal are, according to the medium, the norm of collaboration. Creativity, openness and unconventional thinking 'out of the box' e.g. the medium should therefore be an essential theme of this exercise in class. 
The video analysis showed that the book with its specific structure and its purely visual input leads to an overload via its visual monotony. The effect of overload, perceived as boredom therefore already inhibits motivation after the 3rd picture and should be taken into consideration, when preparing a class with wordless picture books. Based on facial expressions, gestures, participation behavior, the time frame devoted to indexing, and the volume of written texts the reception in class should be limited to a maximum of two pictures in succession. With inclusion of the third picture, not only the motivation but also the concentration decreases considerably, and the amount of expressed ideas declines. Moreover, the willingness to participate in the verbal discussion on the third picture strongly decreases, so that the communication, which until then had been goal-oriented and important for promotion in both the literary-narrative and linguistic sense, is notably reduced. This occasionally leads to a child taking the initiative and usually writing a short story without entering into a discussion. Based on the results so far, a recommendation can therefore be formulated to look at a picture together in a teaching unit in order to get to know the function of the picturebook and then let the children explore one or two further pictures in cooperative group processes.

\subsection{Opening up to multilingual learning}

Dealing with wordless (multimodal) books creates a basis for multilingual approaches. These can help to overcome language barriers and strengthen the children in their individual narrative and media knowledge as well as skills in a migration-related heterogeneous classroom.

The present study shows that children's approaches to multimodal narration do not differ depending on their first and second language. The focus here is on the creativity of the pupils. The same applies to dealing with the change of media. The linguistic differentiation, such as marking the chronological sequence of events, varies depending on the children's age and German learning spent-time. If the selection of the language of communication is analysed in the second round, i.e. with the task of developing stories in the first language, a differentiated picture emerges in the sample. Children with Russian as their first language consistently exchange information in Russian but then they start repeatedly drawing on German words in order to help each other and jointly supplement the appropriate vocabulary. Pupils with Arabic as their first language, on the other hand, use the German language in their negotiation processes. It is only when the results are written down that the first language becomes relevant. Here, however, it becomes noticeable that they often spend a long time looking for individual words in their first language when formulating the results to represent the events precisely. When writing, they concentrate on individual vocabulary and less on the creation of a coherent text. These different approaches in the first languages can be explained by, among other things, different educational experiences, the time, and reason for emigration or even the reputation of the first language. These causes would have to be questioned in practice to be able to respond to 
pupils individually. The opening up of the classroom with regard to the first language and also the change of mode from speech to writing in the treatment of a picture as a story merely represents an increase in complexity which is problematic for the treatment. At the same time, though, it has the

If the multilingualism of children is incorporated into the learning process, the written competences of multilingual children must be assessed in their first languages, as not all children are alphabetized in their first languages or show insecurities in their written expressions potential to consciously apply the narrative skills already developed in the first language and to actively participate in the creative negotiation of the stories. It is precisely these interfaces - between the first and second language, between orality and writing - that must be taken into account when selecting learning arrangements. One has to keep in mind that well-developed competences in the oral language do not necessarily indicate well-developed competences in writing. In inclusive learning settings, therefore, children with AND without German as a second language benefit from linguistic aids that provide them with the necessary orientation to formulate a well-structured, comprehensible written text in German in a way that is appropriate for their age. If the multilingualism of children is incorporated into the learning process, the written competences of multilingual children must be assessed in their first languages, as not all children are alphabetized in their first languages or show insecurities in their written expressions.

This assumption is supported by the observation in the study that showed multilingual children having a lively discussion in German during the decision-making about who is allowed to write. It is decided to take turns. In the second round, the children enjoyed the oral exchange in their first language. When they learned, however, that this time their own story should be written down in their first language, a lengthy discussion ensues as to who should now take on this task:

1 blue2: $\quad$ ты можешь (-) шрифт на русси

[Can you do the russian font? ]

2 blue3: всё я тебе написала теперь ты (-) давай пиши все про твою девочку твою сказку [So I have written everything down for you, write everything about your girl, your fairy tale. ]

3 blue1: $\quad$ я не понимаю что писать (-)

[I don't understand what I'm supposed to write]

4 blue3: что собачка надулась

[That a dog has inflated himself]

5 blue1: $\quad$ я не могу так хорошо писать

[I'm not that good at writing] 
6 blue3: ты сказал что ты хочешь писать пиши

[You said that you want to write, now write! ]

7 blue2: $\quad$ а я сама не могу хорошо писать

[I'm not very good at writing myself. ]

8 blue1: $\quad$ уже не могу хорошо писать

[Now I can't write well either. ]

Figure 5. Group A1 (blue) (L1 Russian, Age: 7/8/8, c-test: 14/44/23; German learning time: 18 months/24 months/born in Germany; picture: Girl with flying dog)

The challenge of dealing with the complex-paradox pictorial-literary narrative form is a unifying element that does not under- or overburden monolingual and multilingual learners with different linguistic preconditions in terms of content, since they are working on an open narrative form that does not prescribe any narrative or linguistic conventions. This can lead to a highly productive discussion, especially in terms of oral communication. Written task formats can tie in with oral communication to develop the educational language skills of the pupils in a targeted manner oriented toward the principles of multilingualism and German as a second language teaching.

This shows us that teachers have to be very careful when assessing the level of knowledge in the first languages, because the pupils assess their own competences in the first languages differently. In addition, we found that linguistic help would have been very helpful for all pupils both - those with German as first language and others with German as second language. We would like to emphasise in particular the need to take age as an essential factor into account, because although these books seem to be suitable for children as young as 3-years old, the narrative complexity is of such a high level, that we would place it differently: the book could be used at the end of primary school earliest, we would rather recommend it for secondary school.

\section{Conclusion}

Our exploratory study concluded that dealing with multimodal wordless picture books is essentially related to the reading socialisation as well as to the media experiences of the recipients. The use of the multimodal wordless picture books offers an innovative potential for learning arrangements. Multimodality within children's literature offers the possibility of using resources beyond the 
traditional book to exploit the full potential of diverse learning structures. For example, when the 'reading' of an interactive wordless picturebook establishes an expanded concept of communication,

Our exploratory study concluded that dealing with multimodal wordless picture books is essentially related to the reading socialisation as well as to the media experiences of the recipients reading, writing and text-comprehension for inclusion-oriented German lessons. This form of multimodality includes picture books as media in the context of further verbal, non-verbal, visual and auditory forms (Abraham \& Kepser, 2016).

The way we used the Was ist denn hier passiert? can be applied to other multimodal picture books with unconventional storytelling and associated "reading against the grain". In the paradoxical violation of the established reading habits and media socialisations as well as children's expectation from a reading process, the central opportunity of these unconventional multimodal picture books for heterogeneous learning settings can be characterized as the joint acquisition of narrative, media, linguistic and communicative competences. The complex task of thinking backwards is consistent with the conviction of Frickel and Kagelmann (2016) that literature suitable for inclusion should also include sophisticated, advanced literary-aesthetic works, and that these works must be integrated into conceptual considerations. Besides the format of literacy, the core aspect here is to enable a wide variety of receptions and expressions to allow pupils in an inclusive learning setting the possible to choose various forms of participation, which best correspond to their abilities and skills (Schluchter, 2015). The diversity is therefore not only guaranteed by the learning setup, but also by the format of the multimodal artifact. The multimodal opening makes the content accessible, without losing its

Multimodal, multiperspective and multilingual tasks and materials can support the individual approaches of pupils constructing a narrative in their first and second languages and help to lower implicit hierarchies in the classroom literary content (Frederking et al., 2012). Multimodal, multiperspective and multilingual tasks and materials can support the individual approaches of pupils constructing a narrative in their first and second languages and help to lower implicit hierarchies in the classroom. By using media, unconventional storytelling and a call for creativity encourages pupils' own interests and thus also their scope for action are pursued and expanded. Open teaching-learning formats, such as the one we have presented here within our study, combined with multimodal narratives with the use of digital elements, which are enhanced by a follow-up communication, enable all pupils to participate equally. 


\section{References}

\section{Primary sources}

Neuhaus, J. \& Penzek, T. (2015). Was ist denn hier passiert? Ein Bilderbuch mit zwölf Trickfilmen. Tulipan Verlag.

Rhyner, R. (2018). Maulwurf Max: Ein Buch zum Fühlen und Riechen für blinde und sehende Kinder. Wörterseh Verlag.

\section{Secondary sources}

Abraham, U. \& Sowa, H. (2016). Bild und Text im Unterricht. Grundlagen, Lernszenarien, Praxisbeispiele.Klett Kallmeyer.

Abraham, U. \& Kepser, M. (2016). Literaturdidaktik Deutsch. Eine Einführung. Erich Schmidt Verlag.

Ahlers, M. (2017). Digitale Medien im Musikunterricht. https://www.bertelsmannstiftung.de/fileadmin/files/Projekte/Musikalische_Bildung/MuBi_Expertise_Digitale_Medien_im_Musikunt erricht_Ahlers_01.pdf.

Ahrenholz, B., Hövelbrinks, B., Maak, D., Ricart Brede, J. \& Rost-Roth, M. (Ed.) (2013). Berichte und Materialien. www.daz-portal.de.

Ahrenholz, B., Maak, D. (2013). Zur Situation von SchülerInnen nicht-deutscher Herkunftssprache in Thüringen unter besonderer Berücksichtigung von Seiteneinsteigern. Abschlussbericht zum Projekt „Mehrsprachigkeit an Thüringer Schulen (MaTS)", durchgeführt im Auftrage des TMBWK. 2. bearb. Aufl.

Boelmann, Jan M., König, L. (2019). Die Wolkenvölker im Deutschunterricht. Einsatzmöglichkeiten intermedialen literarischen Lernens im inklusiven Unterricht. In G. von Glasenapp, A. Kagelmann \& D.Frickel (Eds.). Der inklusive Blick II. Kinder- und Jugendliteratur im Fokus. (pp. 183-200). Peter Lang Verlag.

Bosch, E. (2014). Texts and Peritexts in Wordless and Almost Wordless Picturebooks. In B. Kümmerling-Meibauer, (Eds.). Picturebooks: Representation and Narration. Routledge, 71-90.

Bucher, H. J. (2010). Multimodalität - eine Universalie des Medienwandels. In Hans Jürgen Bucher et al. (Eds.). Neue Medien - neue Formate. Campus. p. 41-79.

Bucher, H. J. (2012). Multimodalität - ein universelles Merkmal der Medienkommunikation: Zum Verhältnis von Medienangebot und Medienrezeption. In Hans-Jürgen Bucher/ Peter Schumacher, (Eds.). Interaktionale Rezeptionsforschung. Theorie und Methode der Blickaufzeichnung in der Medienforschung. Springer VS. p. 51-82.

Dammann-Thedens, K., Michalak, M. (2011a). Bildnarrationen als Fundament zur Vermittlung von sprachlichliterarischen Kompetenzen in mehrsprachigen Klassen. In Roland Jost \& Axel Krommer (Eds.). Comics und Computerspiele im Deutschunterricht. Schneider Verlag, p. 84-102.

Dammann-Thedens, K., Michalak, M. (2012). Bildnarrationen im Fremdsprachenunterricht - Vermittlung von Bildverstehensstrategien. In Zeitschrift für interkulturelle Fremdsprachendidaktik (2). p. 129-142.

Danner, A. (2009). Geschichten sehen und hören. Wie unterschiedliche ästhetische Aufbereitungen von Kinderliteratur nachhaltiges Lernen fördern können. In Lieber, Gabriele, Jahn, Ina Friederike; Danner, Antje (Eds.). Durch Bilder bilden. Empirische Studien zur didaktischen Verwendung von Bildern im Vor- und Grundschulalter. Schneider Verlag. p. 84-92.

Eckes, T. \& Grotjahn, R. (2006). A Closer Look at the Construct Validity of C- Tests. In Language Testing 2006.26 (3). p. 290-325

Eßer R. \& Nimet T. (2018). Was haben Körper, Körpersprache und Kultur miteinander zu tun? Wie kultur,,spezifisch“ ist Körpersprache? In Hövelbrinks, B., Fuchs, I., Maak, D., Duan, T. \& Lütke, B. Der-Die-DaZ - Forschungsbefunde zu Sprachgebrauch und Spracherwerb von Deutsch als Zweitsprache. Walter de Gruyter $\mathrm{GmbH} \&$ Co. KG. 
Finkbeiner, R. (2018). Narration und Materialität im Bilderbuch. Cahiers d'Études Germaniques 75. http://journals.openedition.org/ceg/4046

Frederking, V. (2013). Identitätsorientierter Literaturunterricht. In V. Frederking, A. Krommer \& C. Meier (Eds.). Taschenbuch des Deutschunterrichts. 3 Bände. Bd. 2: Literatur- und Mediendidaktik. 2. aktual. Aufl. Schneider. (pp.427-470).

Frederking, V., Krommer, A., \& Maiwald, K. (2012). Mediendidaktik Deutsch. Eine Einführung. 2. Auflage. Erich Schmidt Verlag.

Frickel, D. \& Kagelmann, A. (2016). Einleitung. Der inklusive Blick. Die Literaturdidaktik und ein neues Paradigma. In D. Frickel \& A. Kagelmann (Eds.). Der inklusive Blick. Die Literaturdidaktik und ein neues Paradigma. (= Beiträge zur Literatur- und Mediendidaktik, Bd. 33). (pp. 11-34). Peter Lang Edition.

Genette, G. (2014). Paratexte. Das Buch vom Beiwerk des Buches. Suhrkamp.

Haage, A. (2015). Inklusive Medienbildung schafft gemeinsame Erfahrungsräume. In DoliMette, Jg. 5, H. 1. (pp. 13-18).

Hopp, M. \& Lieber, G. (2013). Medienaffine Bilderbücher und ihre Potenziale zur Entwicklung von Medienkritik. In G. Lieber (Eds). Lehren und Lernen mit Bildern. Ein Handbuch zur Bilddidaktik. Schneider Verlag.

Hovious, A., Shinas, V.H. \& Harper, I. (2020). The Compelling Nature of Transmedia Storytelling: Empowering Twenty First-Century Readers and Writers Through Multimodality. Tech Know Learn

Jörissen, B., Kröner, S. \& Unterberg, L. (Eds) (2019). Forschung zur Digitalisierung in der Kulturellen Bildung. kopaed. p. 236

Kalkavan-Aydın, Z. (2016). Mehrsprachige Ressourcennutzung in interaktiven Bilderbuchrezeptionen. Mehrsprachigkeit als Ressource in der Schriftlichkeit, edited by Peter Rosenberg \& Christoph Schroeder. (pp. 25-54). De Gruyter Mouton.

Klimek, S. (2010). Paradoxes Erzählen: Die Metalepse in der phantastischen Literatur. mentis.

Krichel, A. (2020). Textlose Bilderbücher. Visuelle Narrationsstrukturen und erzähldidaktische Konzeptionen für die Grundschule. Waxmann.

Krommer, A. (2016). Digitale Jugendliteratur: Social Media, eBooks und Apps. In Der Deutschunterricht 5, p. 5667

Kruse, I. (2014). Intermediale Lektüre(n). Ein Konzept für Zu- und Übergänge in intermedialen Lehr- und Lernarrangements. In G. Weinkauff, U. Dettmar, T. Möbius, I. Tomkowiak (Eds.). Kinder- und Jugendliteratur in Medienkontexten: Adaption - Hybridisierung - Intermedialität - Konvergenz. (pp. 179-198) Peter Lang Verlag.

Kümmerling-Meibauer, B. (2006). Literacy. In The Oxford Encyclopedia of Children's Literature. Band 2. (p. 452453) Hrsg. von Jack Zipes Oxford University Press.

Kümmerling-Meibauer, B. (2012). Bilder intermedial. Visuelle Codes erfassen. In A. Pompe (Eds.). Literarisches Lernen im Anfangsunterricht. Theoretische Reflexionen. Empirische Befunde. Unterrichtspraktische Entwürfe. (pp. 58-72). Schneider Verlag.

Kümmerling-Meibauer, B. (2015). From baby books to picturebooks for adults: European picturebooks in the new millennium, Word \& Image, 31(3), 249-264. DOI: 10.1080/02666286.2015.1032519

Kümmerling-Meibauer, B. (Eds). (2018). The Routledge Companion to Picturebooks. Routledge.

Kurwinkel, T. (2017). Bilderbuchanalyse. Narrativik, Ästhetik, Didaktik. UTB.

Lieber, G. \& Flügel, B. (2009). Kindgemäß oder kindgerecht? - Über den (Un-)Sinn „kindgemäßer“ Auswahl und Gestaltung von Bildern und bildgestützten Medien. In G. Lieber, I.F. Jahn \& A. Danner (Eds.). Durch Bilder bilden. Empirische Studien zur didaktischen Verwendung von Bildern im Vor- und Grundschulalter (pp.28-38). Schneider Verlag. 
Mayring, Ph. (2015). Qualitative Inhaltsanalyse: Grundlagen und Techniken. Beltz.

Neuhaus, S. (2014). Grundriss der Literaturwissenschaft. UTB GmbH; A. Francke.

Niklas, A. (2012). (Trick)Filme und (Bilder)Bücher. Lesewelten öffnen. In A. Pompe, (Eds.) Literarisches Lernen im Anfangsunterricht. Theoretische Reflexionen. Empirische Befunde. Unterrichtspraktische Entwürfe. (pp. 192204). Schneider Verlag.

Rajewski, I. (2018). Literaturbezogene Intermedialität. In K. Maiwald (Eds.). Intermedialität: Formen - Diskurse Didaktik. (pp. 49-76). Schneider Verlag.

Reese, E. (2015) What good is a picturebook? Developing childern's oral langauge and literacy through shared picturebook reading. In B. Kümmerling-Meibauer (Eds.): Learning from Picturebooks. Perspectives from child development and literacy studies (pp. 194-208). Routledge (Explorations in developmental psychology, 3).

Renck Jalongo, M., Dragich, D., Conrad, N., Zhang, A. (2002). Using Wordless Picture Books to Support Emergent Literacy. Early Childhood Education Journal 29 (3), 167-177.

Ritter, A. (2017). Bilderbuchlesearten von Kindern. Neue Erzählformen im Spannungsfeld von kindlicher Rezeption und Produktion. Schneider Verlag.

Rosebrock, C. \& Nix, D. (2015). Grundlagen der Lesedidaktik und der systematischen schulischen Leseförderung. 7., überarbeitete und erweiterte Aufl. Schneider-Verlag Hohengehren.

Scherer, G. \& Volz, S. (Eds.) (2016). Im Bildungsfokus: Bilderbuchrezeptionsforschung. (Koblenz-Landauer Studien zu Geistes-, Kultur- und Bildungswissenschaften, KOLA 15), WVT.

Schluchter, J.-R. (2015). Inklusive Medienbildung - Eine Skizze. In J.R. Schluchter, (Eds.). Medienbildung als Perspektive für Inklusion. Modelle und Reflexionen für die pädagogische Praxis (pp-17-26) kopaed.

Schmitz, U. (2011) Sehflächenforschung: Eine Einführung. In Hans-Joachim Diekmannshenke, (Eds.): Bildlinguistik: Theorien - Methoden - Fallbeispiele (pp. 23-42). Schmidt.

Schrenker, E., Beyer, M. (2014). Digitale interaktive Bilderbücher im Unterricht. Theoretische Grundlagen und praktische Implikationen. In J. Knopf \& U. Abraham (Eds.), BilderBücher. Bd. 2: Praxis (pp. 141-150) Schneider.

Serafini, F. (2010). Reading Multimodal Texts: Perceptual, Structural and Ideological Perspectives. Children's Literature in Education (41), 85-104

Serafini, F., Kachorsky, D. \& Earl Aguilera (2015). Picturebooks 2.0: Transmedial Features Across Narrative Platforms. Journal of Children's Literature, 41(2), 16-24

Siefkes, M. (2015). How semiotic modes work together in multimodal texts: Towards the explanation of intermodal relations. In 10Plus1, H. 1, p. 113-131.

Tabbert, R. (2010). Postmoderne Bilderbücher. In D. Grenz (Eds.), Kinder- und Jugendliteratur. Theorie, Geschichte, Didaktik (pp.105-126). Schneider.

Thiele, A. \& Bosse, I. (2019). Inklusionsorientierter Literaturunterricht mit (digitalen) Medien. Ein Beispiel für die Auseinandersetzung der Fachdidaktiken mit Inklusion in einer mediatisierten Gesellschaft. In I. Bosse, J.R. Schluchter, I. Zorn (Eds.) Handbuch Inklusion und Medienbildung (pp. 77-93). Beltz Juventa.

Thiele, J. (2003). Das Bilderbuch. In J. Thiele \& J. Steitz-Kallenbach (Eds.). Handbuch Kinderliteratur. Grundwissen für Ausbildung und Praxis (pp. 70-98) Herder Verlag.

Tracy, R. (2008). Wie Kinder Sprachen lernen. Und wie wir sie dabei unterstützen können. (2. überarbeitete Aufl.). Francke Verlag.

Vorst, C. (2017). Bildliteralität entwickeln - intertextuelle und transmediale Spurensuche. In H. Hoppe, C. Vorst \& C. Weißenburger(Eds.) Bildliteralität im Übergang von Literatur und Film. Eine interdisziplinäre Aufgabe und Chance kompetenzorientierter Fachdidaktik. (pp. 17-44)Peter Lang (Studien zur Germanistik und Anglistik, Bd. 25).

Weinkauff, G. \&Glasenapp, G. (2014). Kinder- und Jugendliteratur. Schöningh. 
Wieler, P. (2013). Die Bildergeschichte als Lerngegenstand vs. Geschichtenerzählen zu Bildern mit mehrsprachigen Grundschulkindern. In: T. Becker \& P. Wieler (Hg.). Erzählforschung und Erzähldidaktik heute Entwicklungslinien, Konzepte, Perspektiven (pp. 255-278). Stauffenburg Verlag.

Wieler, P. (2015) Vorlesen ohne Text? Bilderbuchrezeption mehrsprachiger Grundschulkin- der. In: M. Dehn \& D. Merklinger (Hg.): Erzählen - vorlesen - zum Schmökern anregen. Grundschulverband e. V. P. 100 - 113.

How to cite this paper:

Conrad, M., Winter, E., \& Michalak, M. (2021). A Case Study on Interactive Wordless Picturebooks and their Potentials within a Multilinguistic Classroom. Journal of Literary Education, (5), 7-32. doi: 10.7203/JLE.5.20811 